Oktapiandi, Joko Sutrisno, Sunarto. (2019). Analisis Pertumbuhan Ikan Nila yang Dibudidayakan pada Air Musta’mal. Jurnal Bioeksperimen. Vol. 5 (1) Pp. 16-20. Doi: 10.23917/bioeksperimen.v5i1.2795

\title{
ANALISIS PERTUMBUHAN IKAN NILA YANG DIBUDIDAYA PADA AIR MUSTA'MAL
}

\author{
*Oktapiandi; Joko Sutrisno; Sunarto \\ Pascasarjana Ilmu Lingkungan, \\ Universitas Sebelas Maret, \\ Jl. Ir. Sutami 36 A Surakarta 57126, Jawa Tengah, Indonesia. \\ Email: Oktapiandi08@gmail.com
}

\begin{abstract}
Abstrak
Ikan Nila (Oreochromis niloticus) merupakan salah satu hasil perikanan darat yang banyak diminati masyarakat. Budidaya ikan nila menggunakan musta'mal merupakan salah satu upaya peningkatan produksi ikan nila sekaligus konservasi air. Tujuan untuk mengetahui pertumbuhan ikan nila yang dibudidaya menggunakan air musta’mal. Penelitian ini merupakan penelitian eksperimental didukung observasi lapangan. Hasil penelitian menunjukkan bahwa pertumbuhan mutlak $(\mathrm{H})$ ikan nila pada perlakuan A 43, 27 gram lebih tinggi dibandingkan perlakuan B 43,34 gram. Laju pertumbuhan (RG) relatif ikan nila pada perlakuan B 1,39\%/hari, lebih tinggi dari Laju pertumbuhan relatif ikan nila pada perlakuan A 1,36 \%/hari. Pertumbuhan ikan nila yang dibudidaya pada air musta'mal masih baik dibandingkan dengan air biasa.
\end{abstract}

Kata kunci: kualitas air, air musta'mal, ikan nila,

\begin{abstract}
Tilapia (Oreochromis niloticus) is one of the land fisheries products that are in great demand by the community around here. Cultivation of Tilapia using mustamal water is one of the efforts to increase Tilapia production as water conservation. The aim of the reaserch was determining the growth of Tilapia cultivated using mustamal water. This research is an experimental study supported by field observations. The results showed that the absolute growth (H) of Tilapia in treatment $A 43.27 \mathrm{~g}$ was higher than treatment $B 43.34 \mathrm{~g}$. The relative growth rate $(R G)$ of Tilapia in treatment $B$ was $1.39 \%$ per day, higher than the relative growth rate of tilapia at treatment $A 1.36 \%$ per day. The growth of Tilapia cultivated in mustamal water is still good compared to ordinary water.
\end{abstract}

Keywords: water quality, water mustamal, Tilapia,

\section{Pendahuluan}

Ikan Nila (Oreochromis niloticus) merupakan salah satu hasil perikanan darat yang banyak diminati masyarakat karena merupakan sumber protein hewani tinggi (Yue, Lin, \& Li, 2016). Ikan nila mempunyai nilai ekonomi tinggi dan merupakan komoditas penting dalam budidaya air tawar dunia (El-Sayed, 2006). Ikan nila adalah ikan yang paling banyak dibudidayakan kedua di dunia, setelah ikan mas. Ikan nila telah menjadi ikon spesies ikan budidaya air tawar di seluruh dunia dengan jumlah produksi global tahun 2012 mencapai 3.2 million MT (Lee, Nambi, SeonghunWon, Katya, \& Bai, 2016).

Keunggulan ikan nila antara lain mudah dikembangbiakan dan kelangsungan hidup tinggi, pertumbuhan relatif cepat dengan ukuran badan relatif besar, serta tahan terhadap perubahan kondisi lingkungan (Sallata, 2015). Keunggungulan ikan nila antara lain; 1) memiliki resitensi terhadap kualitas air dan penyakit, 2) memiliki toleransi luas terhadap kualitas lingkungan, 3) memiliki kemampuan yang efisien dalam membentuk protein kualitas tinggi dari bahan organik, limbah domestik, dan pertanian, 4) memiliki kemampuan tumbuh yang baik, serta mudah tumbuh dalam budidaya intensif (El-Sayed, 2006).

Budidaya ikan nila menggunakan air mustámal (air bekas) wudhu merupakan salah satu upaya peningkatan produksi ikan nila sekaligus konservasi air, melalui optimalisasi dan efisiensi pemanfaatan sumber daya air (Gupta \& Acosta, 2014). Konservasi sumber daya air mutlak dibutuhkan, sebagai upaya 
menjaga dan melesterikan sumber daya air (Sallata, 2015). Selama ini Pondok Pesantren belum banyak memanfaatkan air mustảmal. Air mustảmal lansung dibauang ke saluran pembuangan air. Lokasi penelitian (Pondok Pesantren Darusy Syahadah) memiliki 621 santri putra dan 56 ustadz (tahun ajaran 2016/2017). Apabila diasumsikan dalam berwudhu setiap jamaah menghabiskan kurang lebih 4 liter air, maka setiap sholat menghabiskan 2.708 liter air, maka dalam sehari semalam (5 kali waktu sholat wajib) akan menghabiskan kurang lebih 13.540 liter air. Sekitar 13.540 liter air mustámal tersebut lansung dibuang ke saluran pembuangan air (Syafriadiman, 2009).

Hasil analisis kualitas air mustamal Pondok Peasantren putra Darusy Syahadah memiliki suhu $27,8^{\circ} \mathrm{C}$, COD 29,03 $\mathrm{mg} / \mathrm{L}$, amonia bebas $\left(\mathrm{NH}_{3}-\mathrm{N}\right) \quad 0,19 \mathrm{mg} / \mathrm{L}, \mathrm{BOD}_{5} 38,48 \mathrm{mg} / \mathrm{L}, \mathrm{pH}$ 6,37, oksigen terlarut (DO) $0,85 \mathrm{mg} / \mathrm{L}$ dan $M P N$ Colifrom < $16 \times 10^{4}$. Berdasarkan Peraturan Pemerintah Republik Indonesia Nomor 82 Tahun 2001 keriteria air mustámal di Pondok Peasantren putra Darusy Syahadah termasuk dalam golongan air kelas IV. Air kelas IV peruntukannya untuk irigasi dan peruntukan lain yang sesuai kriteria air tersebut. Baku mutu air yang direkomendasikan Balai Besar Budidaya Air Tawar tahun 2016 untuk budidaya ikan nila antara lain; suhu $25-30^{\circ} \mathrm{C} 27,8^{\circ} \mathrm{C}$, COD $<12 \mathrm{mg} / \mathrm{L}$, amonia bebas $\left(\mathrm{NH}_{3}-\mathrm{N}\right)<1, \mathrm{pH} 6,5-8,5$, oksigen terlarut $(\mathrm{DO})>5 \mathrm{mg} / \mathrm{L}$. secara umum air musta’mal masih layak digunakan untuk budidaya aikan nila.

Dalam agama Islam air mustảmal tergolong air yang baik, sebagai dijelaskan dalam beberapa hadist salah satunya dari hadist Al-Miswar radhiallahu'anhu "jika Nabi shallallahuialaibi wa sallam berwudhu, mereka (para sahabat) hampir hampir salaing membunuh (karena memperebutkan air bekas wudhu Beliau". (HR. Al-Bukhari). Berdasarkan latar belakang tersebut penelitian ini bertujuan untuk mengkaji pertumbuhan ikan nila yang dibudidaya menggunakan air bekas wudhu serta melihar perbandingan dengan ikan yang dibudidaya pada air biasa (sebagai kontrol).

\section{Material Dan Metode}

Penelitian dilaksanakan selama 2 bulan mulai bulan Maret sampai Mei 2017 bertempat di Pondok Pesantren Darusy Syahadah Kecamatan Simo, Kabupaten Boyolali, Provinsi Jawa Tengah. Analisis kualitas air dilakukan di balai laboratorium Kesehatan Yogyakarta.

Penelitian ini merupakan penelitian eksperimental didukung observasi lapangan. Data penelitian terdiri dari data primer dan data sekunder. Data primer meliputi data hasil analisis kualitas air baku Pondok Pesantren Darusy Syahadah, data hasil analisis kualitas air bekas wudhu, data pertumbuhan ikan nila dan data hasil analisis peroksimat ikan nila. Data sekunder meliputi data jumlah santri putra Pondok Pesantren Darusy Syahadah dan data lain terkait dengan penelitian.

\section{Pelaksanaan Penelitian}

\section{Analisis Kualitas Air}

Analisis kualitas air dilakukan pada air baku Pondok Pesantren Darusy Syahadah sebelum digunakan berwudhu dan pada air bekas wudhu dan setelah menjadi air mustámal. Parameter analisis meliputi $\mathrm{pH}$, suhu, $\mathrm{DO}, \mathrm{COD}, \mathrm{BOD}_{5}$, $\mathrm{NH}_{3}-\mathrm{N}$ dan MPN Colifrom.

\section{Analisis Pertumbuhan Ikan Nila}

Analisis Pertumbuhan Ikan Nila menggunakan 2 perlakuan.

A : Ikan nila yang dipelihara dengan air biasa (kontrol).

B : Ikan nila yang dipelihara dengan air musta'mal.

Ikan nila yang digunakan rata-rata memiliki bobot 52 gram. Pemeliharaan selama 2 bulan di kolam terpal dengan panjang $120 \mathrm{~cm}$, lebar $80 \mathrm{~cm}$, tinggi $90 \mathrm{~cm}$ dan kedalaman air $70 \mathrm{~cm}$. Sebanyak 3 kolam untuk air bekas wudhu dan 1 kolam untuk air biasa (kontrol). Pemberian pakan dilakukan pagi dan sore hari.

Pertumbuhan bobot individu mutlak dihitung dengan rumus (Efendie, 1979) :

Keterangan:

$\mathrm{H}$ : Pertumbuhan mutlak (gr)

Wo : Bobot ikan pada awal budidaya (gr)

Wt : Bobot ikan pada akhir budidaya (gr) 
Laju pertumbuhan relatif yaitu:

Keterangan:

RG : Laju Pertumbuhan Relatif (\%/hari)

Wo : Bobot ikan pada awal budidaya (gr)

Wt : Bobot ikan pada akhir budidaya (gr) (Efendie, 1979)

\section{Hasil dan Pembahasan}

\section{Pertumbuhan Ikan Nila}

Hasil budidaya ikan nila menunjukkan adanya pertumbuhan dari awal hingga akhir budidaya. Parameter pertumbuhan ikan nila berdsarkan indikator pertumbuhan mutlak $(\mathrm{H})$ dan laju pertumbuhan relatif (Tabel 1). Pertumbuhan mutlak ikan nila pada perlakuan A 43,34 gr lebih tinggi dibandingkan pertumbuhan mutlak ikan nila pada perlakuan B 43,27 gr (Tabel 1). Sebaliknya data Tabel 2 menujukan laju pertumbuhan relatif ikan nila pada perlakuan A 1,36\%/hari lebih rendah dibandingkan laju pertumbuhan relatif ikan nila pada perlakuan B 1,39\%/hari. Data tersebut juga menujukan tidak terjadi perbedaan pertumbuhan yang signifikan antara perlakuan A dan B.

Tingginya pertumbuhan mutlak pada perlakuan A dan tingginya laju pertumbuhan relatif pada perlakuan B dipengaruhi faktor kualitas air. Kualitas air merupakan salah satu faktor penentu pertumbuhan ikan nila (Ghufran \& Tancung, 2010).

Tabel 1. Pertumbuhan Mutlak Ikan Nila

\begin{tabular}{cccc}
\hline Perlakuan & $\begin{array}{c}\text { Berat awal } \\
\text { (gr) }\end{array}$ & $\begin{array}{c}\text { Berat } \\
\text { akhir } \\
(\text { gr) }\end{array}$ & $\begin{array}{c}\text { Pertumbuhan } \\
\text { Mutlak (H) (gr) }\end{array}$ \\
\hline A & 53,16 & 96,5 & 43,34 \\
B & 51,86 & 95,13 & 43,27 \\
\hline
\end{tabular}

Tabel 2. Laju Pertumbuhan Relatif Ikan Nila

\begin{tabular}{cccc}
\hline Perlakuan & $\begin{array}{c}\text { Berat } \\
\text { awal (gr) }\end{array}$ & $\begin{array}{c}\text { Berat akhir } \\
\text { (gr) }\end{array}$ & $\begin{array}{c}\text { Pertumbuhan } \\
\text { Relatif (RG) (\%/ } \\
\text { hari) }\end{array}$ \\
\hline A & 53,16 & 96,5 & 1,36 \\
B & 51,86 & 95,13 & 1,39 \\
\hline
\end{tabular}

Parameter kualitas air dalam budidaya ikan nila meliputi derajat keasaman $(\mathrm{pH})$, alkalinitas, konsentrasi oksigen terlarut, karbondioksida $\left(\mathrm{CO}_{2}\right)$, salinitas, ammonia, dan kuantitas air (Ghufran \& Tancung, 2010)Pertumbuhan mutlak pada perlakuan A lebih tinggi dibandingkan perlakuan $\mathrm{B}$ disebabkan perbedaan kualitas air (Tabel 3)

Tabel 1. Hasil analisis kualitas air

\begin{tabular}{ccc}
\hline \multirow{2}{*}{ Parameter } & \multicolumn{2}{c}{ Perlakuan } \\
\cline { 2 - 3 } & $27,5^{\circ} \mathrm{C}$ & B \\
\hline Suhu & $<1,03 \mathrm{mg} / \mathrm{L}$ & $29,03 \mathrm{mg} / \mathrm{L}$ \\
\hline $\mathrm{COD}$ & $0,07 \mathrm{mg} / \mathrm{L}$ & $38,48 \mathrm{mg} / \mathrm{L}$ \\
$\mathrm{BOD}_{5}$ & 7,22 & 6,37 \\
$\mathrm{pH}$ & $2,93 \mathrm{mg} / \mathrm{L}$ & $0,19 \mathrm{mg} / \mathrm{L}$ \\
$\mathrm{NH}_{3}-\mathrm{N}$ & 5,69 & 0,85 \\
$\mathrm{DO}$ & $<1,8$ & $16 \times 10^{4}$ \\
$M P N$ Colifrom &
\end{tabular}

Data tabel tersebut menujukan kualitas air perlakuan A lebih baik dibandingkan perlakuan B

Berdasarkan Peraturan Pemerintah Republik Indonesia Nomor 82 Tahun 2001 kualitas air perlakuan A secara garis besar masuk dalam golongan air kelas II. Sedangkan kualitas air perlakuan B secara garis besar masuk dalam golongan air kelas IV. Air kelas II peruntukannya digunakan untuk sarana rekreasi air, pembudidayaan ikan air tawar, peternakan dan irigasi. Air kelas IV peruntukannya untuk irigasi dan peruntukan lain yang sesuai kriteria air tersebut.

Kualitas air perlakuan A merupakan kondisi ideal untuk pertumbuhan ikan nila. Ghufran dan Tancung (2010) menyatakan kualitas air ideal dalam budi daya ikan nila adalah pada kondisi $\mathrm{pH}$ 7-9, Suhu $25-33{ }^{\circ} \mathrm{C}$, kadar Oksigen 5-6 ppm dan salinitas 0-30 ppt (Cai, Leung, Yuan, \& Yuan, 2018). Rekomendasikan Balai Besar Budidaya Air Tawar tahun 2016 untuk budidaya ikan nila antara lain suhu $25-30{ }^{\circ} \mathrm{C} 27,8^{\circ} \mathrm{C}$, COD $<12 \mathrm{mg} / \mathrm{L}$, amonia bebas $\left(\mathrm{NH}_{3}-\mathrm{N}\right)<1$, pH 6,5-8,5, oksigen terlarut $(\mathrm{DO})>5 \mathrm{mg} / \mathrm{L}$. Kualitas air yang ideal untuk pemeliharaan nila sangat diperlukan (Khalil, Mehrim, \& Hassan, 2012)

Meski kualitas air pada perlakuan A lebih baik dan lebih ideal untuk pertumbuhan ikan nila dibandingkan kualitas air perlakuan $B$. Namun kualitas air pada perlakuan B masih dapat digunakan untuk budidaya ikan nila. Disisi lain ikan nila termasuk jenis ikan yang memiliki adaptasi baik terhadap perubahan lingkungan (Hussain, 
2004). Sehingga selisih pertumbuhan mutlak anatra perlakuan A dan B tidak beda jauh atau signifikan (hanya 0,07 gr).

Laju pertumbuhan relatif ikan nila pada perlakuan B lebih baik dibandingkan perlakuan A dengan selisih 0,03\%/hari. Padahal kualitas air perlakuan A lebih baik dibandingkan perlakuan B.

Hal ini menujukan adanya faktor lain dari perbedaan tersebut. Secara tologis agama Islam air mustảmal (perlakuan B) diyakini memiliki keutamaan tersendiri. Dalam beberapa hadist dijelaskan keutamaan air musta'mal. (1) Hadist dari hadist Al-Miswar radhiallahu'anhu "jika Nabi shallallahu'alaihi wa sallam berwudhu, mereka (para sahabat) hampir hampir salaing membunuh (karena memperebutkan air bekas wudhu Beliau". (Hadist Riwayat Al-Bukhari). (2) Hadist dari Ar Rubayyi', "Nabi shallallahu 'alaihi wa sallam pernah mengusap kepalanya dengan bekas air wudhu yang berada di tangannya" (Hadist Riwayat Abu Daud). (3) Hadist dari Jabir, "Rasulullah shallallahu 'alaihi wa sallam pernah menjengukku ketika aku sakit dan tidak sadarkan diri. Beliau kemudian berwudhu dan bekas wudhunya beliau usap padaku. Kemudian aku pun tersadar" (Hadist Riwayat Al-Bukhari).
Dari penjelasan hadist-hadist tersebut tersyirat tentang nilai-nilai kebaikan air mustảmal. Hasil penelitian Emoto (2003) menemukan bahwa partikel kristal air terlihat menjadi indah dan mengagumkan apabila mendapat reaksi positif disekitarnya, misalnya dengan kegembiraan dan kebahagiaan, namun partikel kristal air terlihat menjadi buruk apabila mendapat efek negatif disekitarnya, seperti kesedihan dan bencana (Tribunnews edisi 19 Desember 2014). Air musta'mal menjadi lingkungan tempat hidup ikan nila yang dibudidaya. Lingkungan yang baik (air) akan berkontribusi positif terhadap ikan nila. Kondisi tersebut akan mempengaruhi pertubuhan, perkembangan dan kualitas gizi ikan nila yang dibudidayakan dengan Air musta’mal.

\section{Simpulan}

Pertumbuhan mutlak $(\mathrm{H})$ ikan nila (Tilapia) pada perlakuan A 43,27 gram lebih tinggi dibandingkan perlakuan B 43,34 gram. Laju pertumbuhan $(\mathrm{RG})$ relatif ikan nila pada perlakuan B 1,39\%/hari, lebih tinggi dari Laju pertumbuhan relatif ikan nila pada perlakuan A 1,36\%/hari.

\section{Daftar Pustaka}

Cai, J., Leung, P., Yuan, X., \& Yuan, Y. (2018). Improving the performance of tilapia farming under climate variation-Perspective from bioeconomic modelling. Rome, Italy: Food and agriculture organization of the United Nations .

Efendie, M. (1979). Biologi Perikanan. Bogor, Indonesia: Yayasan Pustaka Nusantara.

El-Sayed, A.-F. M. (2006). Tilapia Culture. Wallingford, Oxfordshire, UK: CABI Publishing is a division of CAB International.

Ghufran, K., \& Tancung, B. (2010). Pengelolaan Kualitas Air Dalam Budi Daya Perairan. Jakarta, Indonesia: Rineka Cipta.

Gupta, M. V., \& Acosta, B. O. (2014). A review of global tilapia farming practices. Aquaculture center, 7-16.

Hussain, M. (2004). FARMING OF TILAPIA-Breeding Plans, Mass Seed Production and Aquaculture Techniques. Mymensingh 2201, Bangladesh : Bangladesh Fisheries Research Institute .

Khalil, F. F., Mehrim, A. I., \& Hassan, M. E. (2012). Effects of hydroyeast aquaculture as growth promoter for adult nile tilapia Oreochromis niloticus .J. Animal and Poultry Prod., Mansoura Univ., Vol.3 (6): 305 - 317.

Lee, S., Nambi, R. W., SeonghunWon, Katya, K., \& Bai, S. C. (2016). Dietary selenium requirement and toxicity levels in juvenile Nile tilapia, Oreochromis niloticus. Aquaculture, 404 : 153-158.

Sallata, M. K. (2015). Konservasi Dan Pengelolaan Sumber Daya Air Berdasarkan Keberadaannya Sebagai Sumber Daya Alam. Info Teknis EBONI, Vol. 12 No.1 : 75 - 86 . 
Syafriadiman. (2009). Teknik Pengelolaan Kualitas Air Budidaya Perikanan Pada Era Industrialisasi . Riau, Indonesia: Universitas Riau Press.

Yue, G. H., Lin, H., \& Li, J. (2016). Tilapia is the Fish for Next - Generation Aquaculture. International Journal of Marine Science and Ocean Technology (IJMO), 3(1), 11-13. 